\title{
Immigration and careers of European workers: effects and the role of policies
}

\author{
Cristina Cattaneo ${ }^{1}$, Carlo V Fiorio ${ }^{2}$ and Giovanni Peri ${ }^{3 *}$
}

\author{
*Correspondence: \\ gperi@ucdavis.edu \\ ${ }^{3}$ Department of Economics, UC \\ Davis, One Shields Avenue, Davis, \\ CA 95616, USA \\ Full list of author information is \\ available at the end of the article
}

\begin{abstract}
In this paper we analyze the response of career, employment and wage of native Europeans to immigration. We then ask how individual country's policies affect these responses. We use data on 11 EU countries, over the period 1995-2001. We also use the 1991 distribution of immigrants by nationality across European labor markets to construct a version of the enclave-based instrument to proxy for the flow of immigrants, that is exogenous to local demand shocks. We find that native Europeans are more likely to upgrade to more skilled and better paid occupations, when a larger number of immigrants enter their labor market. We find no evidence of an increased likelihood of non-employment or geographical mobility. We find that more flexible labor markets in a country are a key factor to have employment upgrading in response to immigration.
\end{abstract}

JEL Codes: J61; 015

Keywords: Immigrants; Europe; Occupation upgrading; Mobility; Labor market policies

\section{Introduction}

The long-run trends of growing international migrations have brought significant change to European Labor Markets during the last 20 years. Since 1995 the percentage of immigrants in Western Europe has grown substantially. As of 2009 about $12 \%$ of the resident population in the European Union was foreign-born. Only ten years earlier that percentage was less than 6\% (Dustmann and Frattini 2013). As immigrants supply specific types of skills and concentrate their employment in some occupations, their effect on native labor market outcomes depends on how much these jobs compete with those performed by natives, or instead how complementary they are to natives' jobs. The effect also depends on the response of natives to immigration, as they may change their occupation to take advantage of their specific skills, vis-a-vis immigrants (Peri and Sparber 2009, D'Amuri and Peri forthcoming). The literature has so far mainly analyzed the impact of immigration on regional or national wages and employment of natives (or some subgroups of them) as outcomes finding mostly small wage and employment effects of immigration on native aggregate outcomes both in Europe (Dustmann et al. 2013, D’Amuri et al. 2010, Glitz 2012) and in the US (Ottaviano and Peri 2012, Card 2009) ${ }^{1}$.

Labor markets are in continuous flux. People enter and exit them, young people join and old people leave them, workers move from an occupation to another and these flows may be affected by immigration. The speed of these flows and transitions may be

(O2013 Cattaneo et al.; licensee Springer. This is an Open Access article distributed under the terms of the Creative Commons Attribution License (http://creativecommons.org/licenses/by/2.0), which permits unrestricted use, distribution, and reproduction in any medium, provided the original work is properly cited. 
affected, among other things, by the labor market institutions and polices of a country. In this paper, we analyze how an inflow of immigrants affects native labor market outcomes, measured in terms of occupational upgrading or downgrading, transition into non-employment and geographical mobility. We use a longitudinal panel of individuals, representative of the European native workers, to compute the outcomes at individual level. We then collapse them in country-year-occupation cells. By comparing similar workers, some of whom were in labor markets exposed to large inflows of immigrants and others who were not, and by following them in the following years of their careers, we analyze how the competition/complementarity with immigrants affected them. We also introduce a genuine "dynamic" component to the analysis of the effects of immigration, by considering the response of native labor market outcomes after two, three and four years from the inflow of immigrants. We focus the analysis on the consequences of immigration for native workers who were already working when immigrants entered the labor market.

We use the European Community Household Panel (ECHP), that contains a representative panel of individuals for the European Union. The ECHP is a European survey, that was designed to provide a representative and cross-nationally consistent picture of households and individuals on a range of topics, including income, health, education, housing, demographics and employment characteristics. The survey, designed as a longitudinal panel, was conducted between 1994 and 2001, in eight successive waves in 12 European countries, with a standardized methodology. The ECHP was designed to be representative for native households. In order to compute the share of immigrant population by country, year and occupation group (needed to measure the supply shock), we use the harmonized European Labour Force Survey (ELFS) instead. This second database is larger and representative of the whole population in EU countries, but it is a repeated cross section.

The inflow of immigrants in country/occupation cells may be correlated with economic and labor market shocks in those cells, causing omitted variable bias. In order to estimate the casual impact of immigrants on native outcomes we use an instrumental variable approach. We construct an instrument (variation of the one used by Altonji and Card 1991, followed by Card 2009, Peri and Sparber 2009, Lewis 2011 and now standard in this literature) by imputing new immigrants across country-occupations based on where previous immigrants from the same countries already were. We construct the imputed inflow of immigrants based on the 1991 immigrant distribution across countries and occupations and on the aggregate flows by country of origin between 1991 and 2001. We then use these imputed flows as instrument for the actual flow of immigrants. We also control for country-time and occupation-time fixed effects that capture shifts in macro economic variables and technological shocks over time.

The other advantage of this dataset is that it includes 11 different countries with different labor market and product market institutions and policies. This allows us to analyze how those policies affected the labor market response to immigration. This allows to shed light on which policies help absorb immigrants in labor markets, granting the highest benefit to natives and if there are combination of policies/institutions that are particularly effective.

The main findings of the paper are as follows. First we find that an increase in the share of immigrants in a local labor market (country-occupation cell) increases the probability that a native worker upgrades his/her job in the next two to four years to a better 
paid and higher "ranked" occupation. Grouping labor market occupations in four tiers defined as "Elementary", "Clerical and Craft", "Technical and Associate" and "Professional and Manager" we find that an increase in the share of immigrants by one percentage point of employment in an occupation-country-year cell increases by 0.8 to $1.1 \%$ the probability that a native worker moves to a higher ranked tier within the following two years. Second, we find that in response to immigration there is no change in the probability that a worker exits employment in the following two to four years, while we find a weak evidence that immigration causes occupational downgrade, but only within a two-year interval. We also find no evidence that immigration is responsible for geographical mobility of natives within a country. Finally we find that more flexible labor markets are a very important characteristic to encourage such mobility. We also find that more regulated product markets, in which profits may be shared between employers and high-level employees, seem also to encourage native workers to upgrade their occupation, possibly in order to participate to profit sharing that may be boosted by immigrants.

Overall the story suggested by our empirical results is that immigrants speed up the transition of natives to higher ranked occupations. These effects are stronger in those countries with flexible labor market policies and competitive product markets. The rest of the paper is organized as follows. Section 2 frames the contribution of this paper within the existing literature. In Section 3 we present the empirical framework of analysis. Section 4 presents the dataset and the main variables and section 5 describes our main results. Section 6 analyzes the role of policies and section 7 concludes the paper.

\section{Literature review: immigrants, labor market institutions and labor market outcomes}

The large part of studies analyzing the impact of immigrants on native labor market outcomes (such as Borjas 2003, Card 2009, Ottaviano and Peri 2012, Dustmann et al. (2013)) approach the issue by defining labor markets cells (regions and/or skills) and the specific demand and supply of workers in that cell. In such framework, changes in the supply of immigrants in the cell are related to changes in wages of natives, interpreted as changes in their marginal productivity. In presence of wage rigidities or upward sloped labor supply, immigration may also cause changes in native employment. Most of the studies use annual (short-run) or decade (long-run) variation in immigrant population (or employment) to identify the effects on average native wages or aggregate employment. The data used in those studies are "pseudo-panels". They are constructed using repeated cross sections of individuals (obtained from Census or Labor force survey) organized in "cells" such as regions, skill or region/skill groups and then each cell (not the individuals) are followed over time. Some papers specifically analyze the dynamic effect of immigration on natives. For example, Cohen-Goldner and Pasermann (2011) distinguish between the short-run and medium-run effects of immigrants on wages and employment of natives by considering the effect of immigrants arrived at different times in the past. Peri and Sparber $(2009,2011)$ and D'Amuri and Peri (forthcoming) focus on the "dynamic response" of natives, by analyzing whether natives move to more complex jobs as a consequence of immigration. Natives may respond to immigration by changing their specialization (as suggested in Peri and Sparber 2009) or by investing in firms' specific skills (as suggested by the wage dynamics in Cohen-Goldner and Pasermann 2011) or by 
undertaking other changes. These responses may take some time and may have effects even when the individuals move out of the original labor market (or upgrade from the original occupation) where the competition with immigrants first affected them.

The role of labor market institutions, specifically their unemployment insurance system, their hiring and firing procedures, the degree of wage centralization and other related policies, has been considered since the seminal contributions of Nickell (1997) and Scarpetta (1996) an important determinant of the unemployment rate and labor market outcomes of countries. In particular those studies aimed at determining whether more rigid and protective labor market institutions could explain the cross sectional difference in employment and unemployment rates across OECD countries. Scholars, however, soon recognized that labor market institutions had not changed much over the previous decades, but unemployment rate, after the 70's had diverged between continental European countries (such as France, Italy and Germany), and the UK and US. Hence, Blanchard (2006), Blanchard and Wolfers (2000) and a series of studies after them, began to study the interactions between macroeconomic shocks of the 70's (oil shock, inflation shocks, productivity slowdown) and labor market institutions. These studies argued that the emergence of turbulent conditions in the labor markets, paired with the sclerotic institutions are the determinants of high unemployment in some countries. The rigidity of labor markets, determined by their institutions, was considered as a key mechanism to perpetuate the unemployment effects of the shocks. Similarly, and even closer to our approach, studies such as Boeri and Terrel (2002) began analyzing the role of labor market institutions in affecting labor reallocation in transition economies. Our paper considers the role of labor market institutions in affecting the ability of workers to respond to immigration shocks by transiting across jobs. In a sense this is a straightforward extension of the literature described above. We analyze a specific aggregate shock (immigration) and its effect on transitions across occupations (rather than unemployment) as outcome. Only few papers (Angrist and Kugler (2003) and D’Amuri and Peri (forthcoming)) have explicitly analyzed the relation between institution and the response to immigration.

\section{Empirical framework and implementation}

In this section we discuss the empirical specification that we estimate and we then discuss our identification strategy and the construction of the instruments.

\subsection{Basic specification}

The variable of interest in this paper is the presence of immigrants measured as the share of foreign born in an occupation-country-year cell $\left(f_{j, c, t}\right)$. We relate this variable to several subsequent outcomes for the average native worker in the same cell, controlling for fixed effects and other explanatory variables. Outcomes for native workers are observed at the individual level. However, in order to best exploit the level of variation of the explanatory variable, we collapse the individual observations by country-year-occupation cells. The most demanding specification we estimate is as follows:

$$
y_{j, c, t, t+r}=\phi_{j}+\phi_{c}+\gamma_{t}+\phi_{c, t}+\phi_{j, t}+\delta X_{j, c, t}+\beta f_{j, c, t}+u_{j, c, t}
$$

In 1 the variable $y_{j, c, t, t+r}$ captures the change, between $t$ and $t+r$ of different individual outcomes (dummy for upgrading/downgrading occupation, or being employed, or moving geographically, or log wage change) aggregated across individuals in the cell. Let us 
emphasize that the dependent variables are individual changes in outcome, that eliminate individual level effects and differences in composition, as the group of individuals aggregated is kept uniform between $t$ and $t+r$. The other controls are occupation $\left(\phi_{j}\right)$ country $\left(\phi_{c}\right)$ and year $\left(\gamma_{t}\right)$ fixed effects as well as some time varying individual controls, collapsed by occupation-country-year cell $\left(X_{j, c, t}\right)$. We also include a set of occupation by year fixed effects $\left(\phi_{j, t}\right)$, which captures shocks such as changes in technology and in relative demand, that are occupation specific and a set of country by year fixed effects $\left(\phi_{c, t}\right)$, which control for shocks related to political, financial or institutional changes and likely to be country specific. Finally, $u_{j, c, t}$ is a cell-specific, zero average random error. This specification aggregates the dependent variable at the same level as the main explanatory variable of interest.

The coefficient of interest is $\beta$ which captures the correlation between immigration in the occupation-country-year cell in year $t$ and the change in average native outcome between year $t$ and year $t+r$. In particular, an increase in the presence of immigrants in a local market may induce and increase in the outflow of natives from that market. We focus on the possibility that the response of natives is in the occupational space and we see if they significantly upgrade or downgrade their occupation. Given the sample period, we estimate outcomes for $r=2, r=3$ or $r=4$ years.

The first outcomes that we consider are occupational upgrading and downgrading. Our data has a definition of occupations that can be easily organized (as we illustrate in the next section) into four "tiers" with a clear ranking. These tiers, in fact, are associated with different levels of wage, education, use of cognitive and complex skills. Ranking those tiers with respect to any of those variables would provide the same ordering. Namely, from the lowest to the highest tier, we grouped occupations into "Elementary", "Clerical and Craft", "Technical and Associates" and "Managers and Professionals". Occupational upgrading is coded with a dummy equal to 1 if an individual changes occupation moving from a lower to a higher tier between $t$ and $t+r$ and is equal to 0 otherwise. For this outcome we only selected those individuals who can actually perform upgrade, i.e excluding those who already are at the top tier at time $t$. Occupational downgrading is coded with a dummy equal to 1 if an individual changes occupation moving from a higher to a lower tier between $t$ and $t+r$ and is equal to 0 otherwise. Those who are at the bottom tier at time $t$ are excluded from this sample. The second type of outcome that we consider is the transition of individual $i$ into non-employment. This is a dummy equal to 1 if the individual exits employment (either joining the group of unemployed or quitting the labor force) between $t$ and $t+r$ and 0 if his/her employment status remains unchanged. The third outcome is geographical mobility of native workers, computed as a dummy equal to 1 if the individual changes location within the country between $t$ and $t+r$ and 0 otherwise. The fourth outcome is the change in logarithmic wage and salary earnings for individual $i$ between $t$ and $t+r$. Finally, focusing on the probability of upgrading to higher-tier occupations in a two-year interval, we also test whether the transition probabilities are affected by national institutions and policies. In particular we divide countries into groups with relatively high and low level of public social expenditures, between countries with low and high employment protection legislation (EPL) and between countries with high and low product market regulation (PMR). These indices capture the intensity of the protective social net in a country, which can affect the willingness of an individual to take risks in changing occupation. They capture the degree of sluggishness of the labor markets, 
that may affect speed and probability of occupational transitions. They finally measure the degree of overall competition on the goods market, that may affect market structure and the bargaining power of employers and hence the possibility of workers to participate to profit sharing, which may also be affected by immigration if capital is complement to immigrant workers. Before moving to results, we provide some additional details on the identification strategy adopted in the next section.

\subsection{Identification and instrumental variable}

The goal of the empirical analysis is identifying and estimating consistently the parameter $\beta$ in equation (1) so that it can be interpreted as the causal effect of immigration on individual outcomes, aggregated by cells. The first challenge to this is the presence of omitted variable bias. Specific labor markets, defined as occupation-country-year cells, might experience expansion or contraction of their demand in a certain year due to technological change, changes in a country economic outlook, changes in macroeconomic variables and other. Those shocks could affect the inflow of immigrants as well as individual outcomes for native workers, generating a spurious correlation. Fixed effects that capture those shocks partially address this concern. Changes in technology, such as adoption of computers, the progress of information technology, the change in the relative demand across sectors are controlled for with the inclusion of the occupation by year fixed effects $\left(\phi_{j, t}\right)$. Country-specific shocks driven by political, financial or institutional evolutions are controlled for by the inclusion of the country by year fixed effects $\left(\phi_{c, t}\right)$. In the most demanding specifications we include both sets of effects. Moreover, as there could be some slowly changing factors that affect upgrading in different occupation-country cells differently (and correlated with migration) we also control for the lagged value of the dependent variable, identifying the effect of immigration only on changes over time. Notice that these sets of fixed effects are in line with those used in the literature that analyzes the wage and employment impact of immigrants across skill groups in national economies (Borjas 2003, Ottaviano and Peri 2012). Those studies proceed to estimate the impact of immigrants using OLS, once the fixed effects are controlled for.

To go beyond the national skill-level approach and exploit the pre-determined distribution of immigrants across country-occupation cells to deal with the potential remaining unobserved shocks we adopt an instrumental variable strategy. We use the fact that, using national Censuses in 1991, we can observe the distribution of immigrants from nine different areas of origin across European countries and occupational groups. ${ }^{2}$ In particular, we compute $s h_{j c 1991}^{N}$ as the share of immigrants of area of origin $N$ in country $c$ and occupation $j$, as measured in year 1999, out of all immigrants of area of origin $N$ in country $c$. We then use the OECD data on net migrant flows in each European country by area of origin $\left(\Delta F_{c, t}^{N}\right)$ to obtain the total number of foreign born from each area, in each year, in each destination. From the censuses of 1991 we can also calculate the total number of foreign-born from area of origin $N$ in European countries, $F_{c, 1991}^{N}$. Hence the number of foreign-born from area of origin $N$ in European country $c$ in year $t$ is constructed as $\widehat{F}_{c, t}^{N}=F_{c, 1991}^{N}+\sum_{s=1992 \ldots t} \Delta F_{c, s}^{N}$. We then allocate the total population of each area of origin-destination country to occupations according to their shares $s h_{c j 1991}^{N}$. The "imputed" number of immigrants of area of origin $N$ in occupation $j$ and country $c$ will therefore be: $\widehat{F}_{j, c, t}^{N}=\widehat{F}_{c, t}^{N} * s h_{j, c, 1991}^{N}$. The total imputed number of foreign-born in that country-occupation-year cell is obtained by summing across areas of origin so that 
$\widehat{F}_{j, c, t}=\sum_{N} \widehat{F}_{j, c, t}^{N}$. We then divide this imputed immigrant population in occupation $j$ and country $c$ by the total employment in that cell to obtain $\widehat{f}_{j, c, t}=\left(\widehat{F}_{j, c, t} / E m p l_{j, c, t}\right)$ which we use as instrument for $f_{j, c, t}$, the share of foreign-born in occupation $j$, country $c$ and period $t$.

The assumption behind this instrument is that the 1991 distribution of immigrants of specific nationality across countries and occupations in 1991 is the result of historical settlements and historical events. Such uneven distribution, combined with networks and preferences for co-location, implies that new immigrants are more likely to move to the same country-occupations in which previous immigrants of the same nationality operate. This is because information on job opportunities travels better in ethnic networks, and immigrants value the possibility of being near other nationals. Hence, in periods of large immigration inflows from a certain countries, cells with larger past presence of immigrants receive a larger inflow, independently from cell-specific labor market condition. The occupation-specific changes in demand after 1991, in fact, do not affect at all the construction of our instrument that only captures the distribution of migrants as of 1991. Hence, the instrument can be thought as proxying for a supplydriven change in immigrants. It should be correlated with the share of foreign-born but not with the region-sector specific demand shocks (remember that we also control for region-time and country-time effects). This strategy to isolate supply-driven changes in immigrants extends the method of Altonji and Card (1991), Card (2001) and Peri and Sparber (2009) to a multi-receiving country setting. Persistent unobserved differences in country-occupation cells, that are correlated with occupational upgrade and past share of immigrants, can still bias the estimated effect. As including occupation-country fixed effects resulted in much weaker instruments, we dealt with these persistent tendencies by including the lagged dependent variable as an additional control. This implies that the effect of a change in foreign-share is identified, while controlling for the lagged outcome, that is as effect on its change only. ${ }^{3}$

\section{Data and summary statistics}

The main dataset used is the European Community Household Panel (ECHP), a survey based on a standardized questionnaire that involves annual interviewing of a representative panel of households and individuals in each of $11 \mathrm{EU}$ countries. The total duration of the ECHP was 8 years, running from 1994 to 2001. In the first wave a sample of around 60,500 nationally representative households - including approximately 130,000 adults aged 16 years and over - were interviewed in the 12 Member States. Austria, Finland and Sweden joined the project in 1995, 1996 and 1997, respectively. ECHP covers in considerable detail the economic activity and personal income of the individuals interviewed, as well as other topics such as health, education, housing, demographics and employment characteristic.

Within each country, the original sample of households and persons is followed over time at annual intervals. The entry of newly formed households is allowed throughout the waves, provided they contain at least one sample person. In addition, new entry of sample persons consists in individuals who were not eligible in the first wave, as being of age 16 or less at that time. Persons who move or otherwise form or join new households are followed at their new location, within the same country. In this manner, the sample 
reflects demographic changes in the population and continues to remain representative of the population over time, except for losses due to sample attrition. Households formed purely of new immigrants into the population are not included (European Commission 1996). Hence the survey is only representative of natives. Although attrition is a typical problem with panel surveys and ECHP is no exception, its sample dynamics compares well with other similar panels (Peracchi 2002).

While ECHP provides a representative, stable panel of native individuals whose outcomes we measure, in order to measure foreign-born as a share of the population, we use the harmonized European Labour Force Survey (ELFS). This Survey aggregates countryspecific surveys at the European level (see Eurostat 2009). We use only data ranging from 1995 to 2001 since before 1995 data on place of birth are absent in most countries. ELFS is used to construct yearly measures of foreign born shares by occupation and country. It is an aggregation of repeated cross-sections, built with standard sampling techniques, to make them representative of the national labor force, allowing us to capture inflows and outflows of migrants by country and years. The sample size of ELFS is 5 to 10 times larger than the ECHP, depending on the year and country considered, allowing for a more reliable estimate of migrant shares by occupation. Using ELFS we are left with 11 out of EU15 countries (namely Austria, Belgium, Denmark, Finland, France, Greece, Ireland, the Netherlands, Spain, Portugal, and the UK) as for the others there is no information allowing us to distinguish between native and foreign born individuals. ${ }^{4}$

In both data sets we selected only observations relative to working age individuals (15-65). Their occupations are coded according to the 1988 International Standard Classification of Occupations (ISCO), produced by the International labour Office (ILO 1990). The ISCO classification is the result of detailed investigation of national coding of occupations in the European countries and organizes them into a standard and common grouping of occupations (Elias and McKnight 2001). We group the ISCO-88 occupations into four tiers. The first tier ("Elementary") includes occupations that use skills associated with a basic general education, usually acquired by the completion of compulsory education. Examples of occupations in the first tier include postal workers, hotel porters, cleaners, and catering assistants. The second tier ("Clerical and Craft") covers a large group of occupations, all of which require basic knowledge as for the first tier, but also a period of worker-related training or work experience. Occupations classified at this level include machine operation, driving, caring occupations, retailing, and clerical and secretarial occupations. The third tier ("Technical and Associate") applies to occupations that normally require a body of knowledge associated with a period of post-secondary education, but not necessarily up to a college degree level. A number of technical occupations fall into this category, as do a variety of trades occupations and proprietors of small businesses. In the latter case, educational qualifications at sub-degree level or a lengthy period of vocational training may not be a necessary prerequisite for competent performance of tasks, but a significant period of work experience is typical. The fourth tier ("Managers and Professionals") relates to what are often termed professional occupations and managerial positions in corporate enterprises or national/local government such as legislators, senior officials and managers. Occupations at this level typically require a tertiary degree or equivalent period of relevant work experience. Table 1 provides the correspondence between the 4 occupation tiers and the ISCO occupations at 1-digit. Recall that the "first" tier is associated with the lowest skills and the "fourth" with the highest. 
Table 1 The skill content of occupations

\begin{tabular}{ll}
\hline Occupation tiers & ISCO Occupation-1 digit \\
\hline First: "Elementary occupations" & 9. Elementary occupations \\
\hline Second: "Clerical and craft occupations" & 4. Clerks; \\
& 5. Service workers and shop and market sales workers; \\
& 6. Skilled agricultural and fishery workers; \\
& 7. Craft and related trades workers; \\
& 8. Plant and machine operators and assemblers \\
\hline Third: "Technical and associate professionals" & 3. Technicians and associate professionals \\
\hline Fourth: "Professional and manager" & 1. Legislators, senior officials and managers; \\
& 2. Professionals \\
\hline
\end{tabular}

Table 2 shows the distribution of native workers across the four tiers. As we notice from columns $1-2$, overall about $10 \%$ of individual-year observations fall in the first occupational tier, $56 \%$ in the second tier, $13 \%$ in the third and over $21 \%$ in fourth (top) tier occupations. This table also shows frequencies (columns 3-4) of tiers in terms of individuals rather than individual-years, showing that $16 \%$ of individuals ever worked in the first tier, $66 \%$ in the second, $19 \%$ in the third and $26 \%$ in the fourth, for a grand total of 104,344 individual-tier observations. Considering that we have 81,843 individuals in our sample, this table suggests that mobility across occupational tiers is substantial, as one quarter of the European population in the period considered has held occupations in at least 2 different tiers. This finding is also confirmed in Table 3, where a transition matrix between tiers at time $t$ and time $t-2$ is presented. The most likely upgrade occurs between the first and the second tier. However, a high percentage of workers also moved from the third to the fourth tier.

The grouping of the occupations into four different hierarchical tiers is quite natural. The aggregate data reveal that moving from tier 1 to 4 , the percentage of workers with tertiary education increases and so does the level of wage and salary earnings. In addition a higher score in complex skills as well as a lower score in manual skills is associated with higher tiers.

Table 2 Distribution of native workers in the four occupation tiers (\%)

\begin{tabular}{|c|c|c|c|c|}
\hline \multirow[t]{4}{*}{ Occupation tiers } & \multicolumn{4}{|c|}{ All natives } \\
\hline & \multicolumn{2}{|c|}{ By individual-years } & \multicolumn{2}{|c|}{ By individuals } \\
\hline & Freq. & $\%$ & Freq. & $\%$ \\
\hline & $(1)$ & $(2)$ & (3) & (4) \\
\hline First & 29,869 9.53 & 13,256 & 16.20 & \\
\hline Second & 174,497 & 55.69 & 53,921 & 65.88 \\
\hline Third & 42,026 & 13.41 & 15,703 & 19.19 \\
\hline Fourth & 66,933 & 21.36 & 21,464 & 26.23 \\
\hline \multirow[t]{2}{*}{ Total } & 313,325 & 100.00 & 104,344 & 78.44 \\
\hline & & & \multicolumn{2}{|c|}{ (No. of individuals $=81,843$ ) } \\
\hline
\end{tabular}

Average 1995-2001

Source: authors calculation based on ECHP data.

Note: Columns (1) and (2) report statistics by individual-years, summing up to the total sample size. Columns (3) and (4) report frequencies and shares of individual who have ever been of each tier. The total frequency is higher that the number of individuals suggesting that some individuals have been employed in different tiers over the period considered. 
Table 3 Transition matrix

\begin{tabular}{llrrrrrr}
\hline & \multicolumn{7}{c}{ Tier at time t } \\
\cline { 2 - 7 } & & First & Second & Third & Fourth & All \\
\hline \multirow{3}{*}{ Tier at time t-2 } & 72.71 & 4.59 & 1.33 & 0.75 & 9.01 \\
\cline { 2 - 7 } & Second & 24.68 & 89.38 & 15.5 & 9.71 & 56.1 \\
\cline { 2 - 7 } & Third & 1.38 & 3.16 & 74.73 & 7.27 & 14.34 \\
\cline { 2 - 7 } & Fourth & 1.23 & 2.88 & 8.44 & 82.27 & 20.55 \\
\cline { 2 - 7 } & All & 100 & 100 & 100 & 100 & 100 \\
\hline
\end{tabular}

Tier at time $\mathrm{t}$ and $\mathrm{t}-2$

Source: authors calculation based on ECHP individual data.

We base our estimation on the sample of native workers in ECHP, which comprise over 313,000 individual-year observations in our selected sample. Once we collapse the individuals we obtain about 400 year-country-occupation cells. ${ }^{5}$

We also use OECD (2012) data to measure the national level of public social expenditures as \% GDP, and OECD (2011) to define the variables accounting for product market regulation (PMR). ${ }^{6}$ Finally OECD (1999) is used to construct a measure of employment protection legislation (EPL).

We define as foreign born those workers who were born in a country different from the one where they are currently resident. Figure 1 shows the share of foreign born workers in the total population by country (upper panel) and in each of the nine ISCO occupation categories considering the whole European Sample (lower panel). The first shows that EU countries widely differ in their share of foreign workers. Averaging the whole period, in France about $10 \%$ of the working population was foreign-born, and in Belgium that percentage was over 9, while in Finland it was less than $2 \%$ of the population. Breaking down the foreign born population of workers by ISCO codes, one notices that foreign-born workers are a relatively large share (roughly $8 \%$ ) of workers in elementary occupations but they also constitute a large share (about 6-7\%) of those employed in occupations requiring high qualifications (such as professional, legislators, senior officials and managers).

\section{Main empirical results}

In this section we present the results of our empirical analysis that estimates the model 1. Tables 4, 5, 6, 7 and 8 and then Table 9 have all the same column structure. In column (1) we show the OLS estimates using the whole sample, in columns (2) and (3) the OLS estimates restricting the sample to the group of countries for which we can build an instrument. Columns (4) to (6) present 2SLS estimations. The basic specifications presented in (1), (2) and (4) include occupation, country and year fixed effects without interactions, plus a number of time varying individual controls, such as the share of native workers in each of three education groups, in industry and tenure groups and the share of married workers in year-country-occupation cell. Specifications (3), (5) and (6) include additional year-country and year-occupation interactions. Finally, specification (6) adds the value of the outcome variable lagged two years.

\subsection{Immigrants and Native job upgrading and downgrading}

In Table 4 we show the estimated values of the coefficient $\beta$ when the dependent variable is the cell-average of a 0-1 dummy capturing the occupational upgrade of individual 

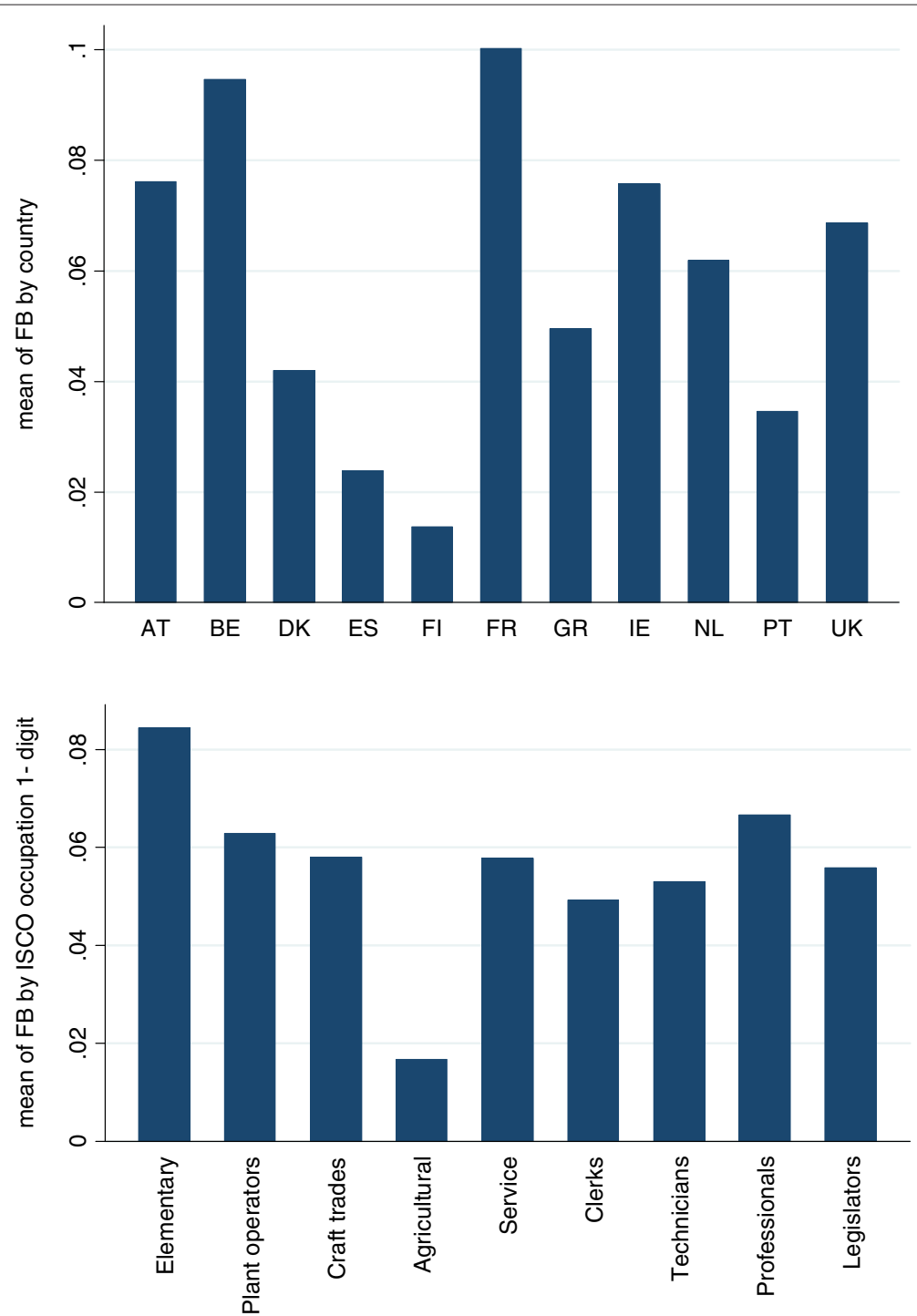

Figure 1 Share (\%) of foreign born workers over total population by ISCO 1-digit. Average 1995-2001. Source: authors' calculations based on ELFS. Note: ISCO occupation 1-digit codes are grouped in Tiers as follows: Elementary occupations = Elementary; Plant and machine operators and assemblers, Craft and related trades workers, Skilled agricultural and fishery workers, Service workers and shop and market sales workers, Clerks = Clerical and Craft; Technicians and associate professionals = Technical and associate; Professionals, Legislators, senior officials and managers = Professionals and managers.

natives between $t$ and $t+r$. In particular, this dummy was defined as equal to one if, during the period between $t$ and $t+r$, individual $i$ (who was in occupation $j$ and country $c$ in year $t$ ) moved to an occupation in a higher "tier". The variable is equal to 0 if individual $j$ did not change or moved to a lower tier. Similarly, in Table 5 we show the estimated values of the coefficient $\beta$ when the dependent variable is the cell-average of a 0-1 dummy capturing the occupational downgrade of natives. This is a dummy equal to one if a native worker moves to an occupation in a lower tier between year $t$ and $t+r$. These outcomes, therefore, account for a "change in status" of natives within the considered period. In the 
first row we consider the outcome over 2 years $(r=2)$, while in the second row we measure the outcome within 3 years $(r=3)$ and in the third row we measure it over 4 years $(r=4)$.

Considering first occupational upgrading (Table 4), the 2SLS results show a significant, robust and stable coefficient estimate across specifications. They show that the effect of immigration on native occupation upgrading is positive, significant and relatively stable over time for all specifications. The 2SLS estimates exhibit larger coefficients than the OLS, implying the presence of measurement error, and possibly that local labor market shocks associated to immigration flows as well as upgrading, may conceal part of the impact of immigration on native occupational upgrading when using OLS as estimation method. The 2SLS estimated effect on occupational upgrading is large and significant even for the most demanding specification. Using the coefficients in column 5, an increase of immigrants by one percentage point of employment in the cell, increases the probability of native workers upgrading their occupation (to one in a higher tier) by $1 \%$ within 2 years, $1.2 \%$ within 3 years and by almost $1.4 \%$ within four years. Considering the average probability of upgrading, an increase in the share of immigrants by 10 percentage points of the cell employment raises the likelihood of a native occupational upgrading from $13 \%$ to $23 \%$ within 2 years interval. The same increase in the share of foreigners increases the probability of native upgrading from 16 to $30 \%$ within four years. Notice also that in most estimates there is a monotonic increase in the effect going from 2 to 4 years. This indicates that the dynamic response of natives may take some time and it exhibits the strongest effect over the longer run. Finally, column (6) presents the empirical findings when the lag of the dependent variable is added to the most demanding specification. The coefficients of interest confirm the positive and significant effect of the inflow of immigrants on the probability of upgrading.

When considering occupational downgrading instead (Table 5), the estimates show that the effect of immigration on native occupation downgrading is sometimes positive, but most of the time much smaller in magnitude than the upgrading effect and usually not statistically significant. In particular considering specification (5), which has the most complete set of fixed effects, we see some potential mild increase in downgrading after 2 years (significant only at the $10 \%$ confidence level) but that effect is actually null over the 4 year period. These findings are overall confirmed in column (6). We should interpret with caution, however, the result of the 4-year interval, where the lagged of the dependent variable is included. The instrument in this specification is too weak to draw robust conclusions.

The two results together imply that an increase in the presence of immigrants within a labor market, represented here by an occupation-country cell, increases the mobility of native workers, originally in that occupations, towards more skilled, better paid ones. This confirms that, to protect themselves from competition and to best exploit the complementarity with immigrants, who tend to take manual, routine-intensive type of jobs at the low end of the complexity spectrum, natives upgrade their jobs. Notice also that the F-values of the instrument in the first-stage always pass the test for weak instruments (Stock et al. 2002).

It should be noted that the sample in the 2SLS estimations does not include all the 11 countries available. This is because the 1991 census data, used to compute the instrument, 


\section{Table 4 Immigration and native "occupational upgrading"}

\begin{tabular}{|c|c|c|c|c|c|c|}
\hline \multirow[t]{2}{*}{ Specification: } & (1) & $(2)$ & (3) & (4) & $(5)$ & $(6)$ \\
\hline & OLS & OLS & OLS & $2 S L S$ & $2 S L S$ & $2 S L S$ \\
\hline Occupation upgrade & -0.1427 & 0.2620 & $0.4357^{* * *}$ & $0.8118^{* * *}$ & $1.0510^{* * *}$ & $1.0018^{* * *}$ \\
\hline 2-year interval & {$[0.2019]$} & {$[0.2124]$} & {$[0.1519]$} & {$[0.2372]$} & [0.2303] & {$[0.2541]$} \\
\hline Observations & 348 & 210 & 210 & 210 & 210 & 126 \\
\hline F-stat 1st stage & . & . & . & 70.55 & 44.09 & 48.02 \\
\hline Occupation upgrade & 0.0207 & 0.3310 & $0.6294^{* * *}$ & $0.8466^{* * *}$ & $1.2376^{* * *}$ & $1.8067^{* * *}$ \\
\hline 3-year interval & {$[0.1986]$} & {$[0.2097]$} & {$[0.1647]$} & {$[0.2072]$} & {$[0.2330]$} & {$[0.2172]$} \\
\hline Observations & 272 & 168 & 168 & 168 & 168 & 84 \\
\hline F-stat 1st stage & . & . & & 86.58 & 63.38 & 50.71 \\
\hline Occupation upgrade & 0.2895 & $0.7059^{* * *}$ & $0.9237^{* * *}$ & $1.2148^{* * *}$ & $1.3969^{* * *}$ & $2.2955^{* * *}$ \\
\hline 4-year interval & {$[0.1997]$} & {$[0.1743]$} & {$[0.1320]$} & [0.2433] & [0.1986] & {$[0.2440]$} \\
\hline Observations & 196 & 126 & 126 & 126 & 126 & 42 \\
\hline F-stat 1st stage & . & & . & 60.90 & 47.81 & 7.478 \\
\hline Fixed effects & Country, Year & Country, Year & Country, Year & Country, Year & Country, Year & Country, Year \\
\hline \multirow{2}{*}{ Interaction effects } & \multirow{2}{*}{ No } & \multirow{2}{*}{ No } & Year × Country & \multirow{2}{*}{ No } & Year × Country & Year $\times$ Country \\
\hline & & & Year $\times$ Occupation & & Year $\times$ Occupation & Year $\times$ Occupation \\
\hline Lag dependent & No & No & No & No & No & Yes \\
\hline
\end{tabular}

Note: Each cell reports the estimate from a different regression. The coefficient reported in columns (1) to (6) is the coefficient of interest on the share of individuals upgrading in the year-country-occupation cells, as written at the beginning of each row. The length of the time interval $t, t+r$ is also indicated in the first cell of each row. All regressions are performed at country-year-occupation level and include dummies for occupation, year and countries and the share of European natives in each education group, marital status, industry and tenure group. In brackets we report the standard errors clustered at the country-occupation level. In column (1) the estimates are produced using the whole sample. *,***** indicate significance at the 10,5 and $1 \%$ level. 


\section{Table 5 Immigration and native "occupational downgrading"}

\begin{tabular}{|c|c|c|c|c|c|c|}
\hline \multirow[t]{2}{*}{ Specification: } & (1) & (2) & (3) & (4) & $(5)$ & $(6)$ \\
\hline & OLS & OLS & OLS & $2 S L S$ & $2 S L S$ & $2 S L S$ \\
\hline Occupation downgrade & 0.1196 & $0.5307^{* * *}$ & 0.2464 & $0.8046^{*}$ & $0.5836^{*}$ & -0.4447 \\
\hline 2-year interval & {$[0.1780]$} & [0.1798] & {$[0.1895]$} & {$[0.4134]$} & {$[0.3064]$} & {$[0.4324]$} \\
\hline Observations & 398 & 240 & 240 & 240 & 240 & 144 \\
\hline F-stat 1st stage & . & . & . & 33.67 & 25.87 & 15.22 \\
\hline Occupation downgrade & 0.1796 & $0.4420^{* *}$ & 0.1639 & 0.5153 & 0.2609 & -0.8161 \\
\hline 3-year interval & {$[0.1952]$} & {$[0.1966]$} & {$[0.2348]$} & {$[0.4468]$} & [0.3779] & [0.6998] \\
\hline Observations & 311 & 192 & 192 & 192 & 192 & 96 \\
\hline F-stat 1st stage & . & . & . & 31.55 & 24.31 & 13.24 \\
\hline Occupation downgrade & 0.0629 & -0.1179 & -0.1638 & -0.1687 & -0.5690 & $-1.4912^{* * *}$ \\
\hline 4-year interval & {$[0.2241]$} & {$[0.2178]$} & {$[0.2525]$} & {$[0.4668]$} & {$[0.4723]$} & {$[0.5261]$} \\
\hline Observations & 224 & 144 & 144 & 144 & 144 & 48 \\
\hline F-stat 1st stage & & $\cdot$ & & 16.64 & 15.53 & 5.557 \\
\hline Fixed effects & Country, Year & Country, Year & Country, Year & Country, Year & Country, Year & Country, Year \\
\hline \multirow{2}{*}{ Interaction effects } & \multirow{2}{*}{ No } & \multirow{2}{*}{ No } & Year $\times$ Country & \multirow{2}{*}{ No } & Year $\times$ Country & Year $\times$ Country \\
\hline & & & Year $\times$ Occupation & & Year $\times$ Occupation & Year $\times$ Occupation \\
\hline Lag dependent & No & No & No & No & No & Yes \\
\hline
\end{tabular}

Note: Each cell reports the estimate from a different regression. The coefficient reported in columns (1) to (6) is the coefficient of interest on the share of individuals downgrading in the year-country-occupation cells, as written at the beginning of each row. The length of the time interval $\mathrm{t}, \mathrm{t}+\mathrm{r}$ is also indicated in the first cell of each row. All regressions are performed at country-year-occupation level and include dummies for occupation, year and countries and the share of European natives in each education group, marital status, industry and tenure group. In brackets we report the standard errors clustered at the country-occupation level. In column (1) the estimates are produced using the whole sample. ******* indicate significance at the 10,5 and $1 \%$ level. 


\section{Table 6 Immigration and native exit from employment}

\begin{tabular}{|c|c|c|c|c|c|c|}
\hline \multirow[t]{2}{*}{ Specification: } & (1) & (2) & (3) & (4) & (5) & (6) \\
\hline & OLS & OLS & OLS & 2SLS & $2 S L S$ & $2 S L S$ \\
\hline Out of employment & 0.0672 & $0.0836^{*}$ & 0.0009 & 0.0240 & -0.0465 & $-0.1074^{* *}$ \\
\hline 2-year interval & {$[0.0475]$} & {$[0.0435]$} & {$[0.0369]$} & {$[0.0658]$} & {$[0.0594]$} & {$[0.0522]$} \\
\hline Observations & 449 & 270 & 270 & 270 & 270 & 162 \\
\hline F-stat 1st stage & . & & . & 50.89 & 43.06 & 58.70 \\
\hline Out of employment & -0.0210 & -0.0123 & $-0.0797^{* *}$ & -0.0502 & $-0.1614^{* * *}$ & $-0.2245^{* * *}$ \\
\hline 3-year interval & {$[0.0488]$} & {$[0.0403]$} & {$[0.0362]$} & {$[0.0661]$} & {$[0.0561]$} & {$[0.0535]$} \\
\hline Observations & 351 & 216 & 216 & 216 & 216 & 108 \\
\hline F-stat 1st stage & $\cdot$ & . & . & 74.13 & 61.74 & 51.78 \\
\hline Out of employment & -0.0024 & -0.0364 & $-0.0999^{*}$ & -0.0984 & $-0.2230^{* * *}$ & $-0.3230^{* * *}$ \\
\hline 4-year interval & {$[0.0675]$} & {$[0.0523]$} & {$[0.0567]$} & {$[0.0747]$} & {$[0.0765]$} & {$[0.0769]$} \\
\hline Observations & 252 & 162 & 162 & 162 & 162 & 54 \\
\hline F-stat 1st stage & . & & . & 62.23 & 55.22 & 35.28 \\
\hline Fixed effects & Country, Year & Country, Year & Country, Year & Country, Year & Country, Year & Country, Year \\
\hline \multirow{2}{*}{ Interaction effects } & \multirow{2}{*}{ No } & \multirow{2}{*}{ No } & Year $\times$ Country & \multirow{2}{*}{ No } & Year $\times$ Country & Year $\times$ Country \\
\hline & & & Year $\times$ Occupation & & Year $\times$ Occupation & Year $\times$ Occupation \\
\hline Lag dependent & No & No & No & No & No & Yes \\
\hline
\end{tabular}

Note: Each cell reports the estimate from a different regression. The coefficient reported in columns (1) to (6) is the coefficient of interest on the share of individuals moving from employment to unemployment in the

year-country-occupation cells, as written at the beginning of each row. The length of the time interval $t, t+r$ is also indicated in the first cell of each row. All regressions are performed at country-year-occupation level and include

dummies for occupation, year and countries and the share of European natives in each education group, marital status, industry and tenure group. In brackets we report the standard errors clustered at the country-occupation level. In column (1) the estimates are produced using the whole sample. ${ }^{*}, * * * * *$ indicate significance at the 10,5 and $1 \%$ level. 


\section{Table 7 Immigration and native geographical mobility}

\begin{tabular}{|c|c|c|c|c|c|c|}
\hline \multirow[t]{2}{*}{ Specification: } & (1) & (2) & (3) & $(4)$ & $(5)$ & (6) \\
\hline & OLS & OLS & OLS & 2SLS & $2 S L S$ & $2 S L S$ \\
\hline Reg. mobility & 0.0212 & 0.0221 & 0.0134 & 0.0325 & 0.0040 & 0.0515 \\
\hline 2-year interval & {$[0.0220]$} & {$[0.0255]$} & {$[0.0240]$} & {$[0.0302]$} & {$[0.0308]$} & {$[0.0386]$} \\
\hline Observations & 405 & 270 & 270 & 270 & 270 & 162 \\
\hline F-stat 1st stage & & & & 50.89 & 43.06 & 55.76 \\
\hline Reg. mobility & 0.0129 & 0.0131 & 0.0007 & 0.0136 & -0.0293 & 0.0606 \\
\hline 3-year interval & {$[0.0304]$} & {$[0.0328]$} & {$[0.0340]$} & {$[0.0386]$} & {$[0.0416]$} & {$[0.0589]$} \\
\hline Observations & 315 & 216 & 216 & 216 & 216 & 108 \\
\hline F-stat 1st stage & . & . & . & 74.13 & 61.74 & 61.76 \\
\hline Reg. mobility & $0.2546^{*}$ & $0.3210^{*}$ & $0.4726^{* *}$ & 0.0891 & 0.3901 & $0.5343^{* *}$ \\
\hline 4-year interval & {$[0.1352]$} & {$[0.1856]$} & {$[0.1916]$} & [0.2969] & {$[0.2826]$} & {$[0.2693]$} \\
\hline Observations & 225 & 162 & 162 & 162 & 162 & 54 \\
\hline F-stat 1st stage & & . & & 62.23 & 55.22 & 35.32 \\
\hline Fixed effects & Country, Year & Country, Year & Country, Year & Country, Year & Country, Year & Country, Year \\
\hline \multirow{2}{*}{ Interaction effects } & \multirow{2}{*}{ No } & \multirow{2}{*}{ No } & Year $\times$ Country & \multirow{2}{*}{ No } & Year $\times$ Country & Year $\times$ Country \\
\hline & & & Year $\times$ Occupation & & Year $\times$ Occupation & Year $\times$ Occupation \\
\hline Lag dependent & No & No & No & No & No & Yes \\
\hline
\end{tabular}

Note: Each cell reports the estimate from a different regression. The coefficient reported in columns (1) to (6) is the coefficient of interest on the share of individuals moving within the same country in the year-country-occupation

cells, as written at the beginning of each row. The length of the time interval $t, t+r$ is also indicated in the first cell of each row. All regressions are performed at country-year-occupation level and include dummies for occupation, year and countries and the share of European natives in each education group, marital status, industry and tenure group. In brackets we report the standard errors clustered at the country-occupation level. In column (1) the estimates are produced using the whole sample. * ****** indicate significance at the 10,5 and $1 \%$ level. 


\section{Table 8 Immigration and native wage and salary earnings}

\begin{tabular}{|c|c|c|c|c|c|c|}
\hline \multirow[t]{2}{*}{ Specification: } & $(1)$ & $(2)$ & (3) & (4) & (5) & (6) \\
\hline & OLS & OLS & OLS & 2SLS & 2SLS & 2SLS \\
\hline LogWage change & $-0.4372^{* *}$ & -0.1056 & -0.0513 & -0.1535 & -0.2196 & -0.2167 \\
\hline 2-year interval & [0.1789] & {$[0.1676]$} & {$[0.1415]$} & {$[0.2641]$} & {$[0.2070]$} & {$[0.2138]$} \\
\hline Observations & 449 & 270 & 270 & 270 & 270 & 162 \\
\hline F-stat 1st stage & . & & & 125.8 & 122.4 & 101.8 \\
\hline LogWage change & -0.2376 & -0.1085 & -0.0192 & -0.0216 & 0.1566 & -0.2814 \\
\hline 3-year interval & {$[0.3078]$} & {$[0.2325]$} & {$[0.1760]$} & [0.3559] & {$[0.2445]$} & {$[0.2581]$} \\
\hline Observations & 351 & 216 & 216 & 216 & 216 & 108 \\
\hline F-stat 1st stage & . & . & . & 142.2 & 135.6 & 73.65 \\
\hline LogWage change & -0.0683 & -0.0955 & -0.1321 & 0.1208 & -0.3450 & -0.0612 \\
\hline 4-year interval & {$[0.3491]$} & {$[0.3541]$} & {$[0.1928]$} & {$[0.5769]$} & {$[0.2453]$} & {$[0.2417]$} \\
\hline Observations & 252 & 162 & 162 & 162 & 162 & 54 \\
\hline F-stat 1st stage & & & . & 107.5 & 109.5 & 32.15 \\
\hline Fixed effects & Country, Year & Country, Year & Country, Year & Country, Year & Country, Year & Country, Year \\
\hline \multirow{2}{*}{ Interaction effects } & \multirow{2}{*}{ No } & \multirow{2}{*}{ No } & Year $\times$ Country & \multirow{2}{*}{ No } & Year $\times$ Country & Year $\times$ Country \\
\hline & & & Year $\times$ Occupation & & Year $\times$ Occupation & Year $\times$ Occupation \\
\hline Lag dependent & No & No & $\mathrm{No}$ & No & No & Yes \\
\hline
\end{tabular}

Note: Each cell reports the estimate from a different regression. The coefficient reported in columns (1) to (6) is the coefficient of interest on the average log-difference of wage and salary income in the year-country-occupation cells, as written at the beginning of each row. The length of the time interval $t, t+r$ is also indicated in the first cell of each row. All regressions are performed at country-year-occupation level and include dummies for occupation, year and countries and the share of European natives in each education group, marital status, industry and tenure group. In brackets we report the standard errors clustered at the country-occupation level. In column (1) the estimates are produced using the whole sample. *,**,***indicate significance at the 10,5 and $1 \%$ level. 
Table 9 Immigration and native occupational upgrading

\begin{tabular}{|c|c|c|c|c|c|c|}
\hline & (1) & (2) & (3) & (4) & (5) & (6) \\
\hline & OLS & OLS & OLS & $2 S L S$ & $2 S L S$ & $2 S L S$ \\
\hline \multirow[t]{2}{*}{ High Social Exp } & 0.0534 & $0.5142^{* * *}$ & $0.6572^{* * *}$ & $0.6572^{* * *}$ & $0.8283^{* * *}$ & $0.7695^{* * *}$ \\
\hline & {$[0.1619]$} & [0.1976] & {$[0.1504]$} & {$[0.1504]$} & {$[0.2511]$} & {$[0.2537]$} \\
\hline \multirow[t]{2}{*}{ Low Social Exp } & $-0.4258^{*}$ & -0.0456 & 0.0234 & 0.0234 & $1.1269^{*}$ & $2.2406^{* *}$ \\
\hline & [0.2394] & [0.2154] & {$[0.1748]$} & {$[0.1748]$} & [0.6110] & [0.9490] \\
\hline Observations & 348 & 210 & 210 & 210 & 210 & 126 \\
\hline F-stat 1st stage & . & . & . & . & 4.151 & 3.128 \\
\hline \multirow{2}{*}{ High PMR } & -0.0771 & $0.3758^{*}$ & $0.4642^{* *}$ & $0.4642^{* *}$ & $1.0130^{* * *}$ & $1.1038^{* * *}$ \\
\hline & {$[0.2424]$} & [0.2246] & {$[0.1821]$} & {$[0.1821]$} & [0.1951] & {$[0.2144]$} \\
\hline \multirow[t]{2}{*}{ Low PMR } & $-0.4637^{*}$ & $-0.5882^{* *}$ & -0.2277 & -0.2277 & 0.0186 & -0.1648 \\
\hline & [0.2808] & [0.2968] & [0.3259] & [0.3259] & [0.4536] & [0.5360] \\
\hline Observations & 348 & 210 & 210 & 210 & 210 & 126 \\
\hline F-stat 1st stage & . & 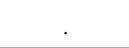 & & . & 36.58 & 22.12 \\
\hline \multirow[t]{2}{*}{ High EPL } & -0.3674 & -0.1559 & -0.0133 & -0.0133 & 0.3053 & $0.9807^{* *}$ \\
\hline & {$[0.2492]$} & [0.1911] & [0.1804] & [0.1804] & [0.3628] & {$[0.4258]$} \\
\hline \multirow[t]{2}{*}{ Low EPL } & 0.0971 & $0.7130^{* * *}$ & $0.7743^{* * *}$ & $0.7743^{* * *}$ & $0.8827^{* * *}$ & $1.0715^{* * *}$ \\
\hline & [0.1598] & {$[0.1781]$} & {$[0.1377]$} & [0.1377] & [0.2098] & [0.2290] \\
\hline Observations & 348 & 210 & 210 & 210 & 210 & 126 \\
\hline F-stat 1st stage & & . & . & & 13.50 & 12.85 \\
\hline \multirow[t]{2}{*}{ High EPL $\times$ High PMR } & -0.3487 & -0.0366 & 0.0627 & $1.0684^{* *}$ & $1.0118^{* *}$ & $1.9461^{* * *}$ \\
\hline & [0.2995] & {$[0.2217]$} & {$[0.1838]$} & {$[0.5119]$} & {$[0.4898]$} & [0.6455] \\
\hline \multirow[t]{2}{*}{ Low EPL $\times$ High PMR } & 0.1879 & $0.7563^{* * *}$ & $0.8281^{* * *}$ & $1.0107^{* * *}$ & $1.0113^{* * *}$ & $0.8860^{* * *}$ \\
\hline & [0.1659] & {$[0.1708]$} & {$[0.1259]$} & {$[0.2040]$} & {$[0.1737]$} & [0.1959] \\
\hline \multirow[t]{2}{*}{ High EPL $\times$ Low PMR } & -0.5188 & $-0.6534^{* *}$ & -0.1869 & -0.0117 & 0.3711 & -0.7037 \\
\hline & [0.3639] & [0.3183] & {$[0.3837]$} & {$[0.4568]$} & {$[0.5064]$} & [0.5792] \\
\hline Low EPL × Low PMR & -0.4797 & -0.2602 & -0.6418 & 0.9586 & -0.2711 & -1.7382 \\
\hline
\end{tabular}




\section{Table 9 Immigration and native occupational upgrading (Continued)}

\begin{tabular}{|c|c|c|c|c|c|c|}
\hline & [0.3414] & {$[0.6752]$} & {$[0.7914]$} & [1.4366] & [1.5022] & [2.0938] \\
\hline Observations & 348 & 210 & 210 & 210 & 210 & 126 \\
\hline First st. F-stat & . & & . & 2.224 & 1.632 & 1.896 \\
\hline Fixed effects & Country, Year & Country, Year & Country, Year & Country, Year & Country, Year & Country, Year \\
\hline \multirow{2}{*}{ Interaction effects } & \multirow{2}{*}{ No } & \multirow{2}{*}{ No } & Year $\times$ Country & \multirow{2}{*}{ No } & Year $\times$ Country & Year $\times$ Country \\
\hline & & & Year $\times$ Occupation & & Year $\times$ Occupation & Year $\times$ Occupation \\
\hline Lag dependent & No & No & No & No & No & Yes \\
\hline
\end{tabular}

By Employment Protection Legislation, Product Market Regulation and Social Expenditure levels.

Note: Each cell reports the estimate from a different regression. The coefficient reported in columns (1) to (6) is the coefficient of interest on the probability of upgrading to a higher-tier occupation in a two-year interval, by groups of

the total sample divided by level of Social Expenditure, Employment Protection Legislation (EPL) and Product Market Regulation (PMR), as written at the beginning of each row. All regressions are performed at country-year-occupation level and include dummies for occupation, year and countries and the share of European natives in each education group, marital status, industry and tenure group. In brackets we report the standard errors clustered at the country-occupation level. In column (1) the estimates are produced using the whole sample. ${ }^{*}, * * * * * *$ indicate significance at the 10, 5 and $1 \%$ level. 
were available only for six of the 11 countries, namely France, UK, Greece, Spain, Portugal and Austria. ${ }^{7}$

Altogether, these results imply that immigration promotes a response of natives in terms of occupational specialization and career. By filling several jobs at the "low" end of the occupational spectrum many immigrants generate opportunities (and increase demand) for jobs in higher occupational tiers, that can be filled by natives. Native workers appear to take advantage of these opportunities (these dynamics have also been discussed in previous studies, such as Peri and Sparber 2009). Our results show that in countries in which the inflow of immigrants has been larger, natives have on average been pushed to climb more rapidly the ladder of occupational opportunities. Natives are relatively more likely to advance than to regress in their progression from simpler and less paid jobs to more complex and better paid jobs when immigrant take jobs at the lower rungs of the occupational ladder. The present study shows that the higher concentration of natives in higher-ranked occupations, in response to immigration, is not the result of compositional changes but existing native individuals, those identified in our longitudinal dataset, move more rapidly to higher ranked occupations. This beneficial externality could be partly off-set by switching costs, if any, but we are unable to test this hypothesis with these data.

\subsection{Effects on employment and geographical mobility}

While the mobility towards higher occupational tiers is certainly a positive outcome for natives, it may imply, in the short and medium run, higher risks of searching for a new job. A modified version of the "crowding-out" hypothesis (that argues that immigrants decrease the job opportunities for natives) would imply that immigrants push natives to move to other occupations, increasing their transitional periods in non-employment. While immigrants may create complementary opportunities for natives, beneficial in the long-run, the fact that natives have to change occupation to take advantage of those opportunities may leave them unemployed, or out of the labor force for a while. Moreover, while on average workers upgrade their jobs, some workers may be left without one for long time, because immigrants crowd their opportunities in lower occupational tiers or because other natives compete with them, pushed from lower tiers.

To test these possibilities we consider as outcome a dummy equal to 1 if individual $i$ goes from employed to non-employed between year $t$ and $t+r$. For each individual, the dummy is equal to 0 if individual $i$ does not change the employment status or becomes employed. In particular, as the employment status of a person is measured in a specific month of the year, we are testing whether larger presence of immigrants increases the probability of a native individual to be unemployed during that particular week. Hence, the outcome $y$ at the occupation-country-year level is the share of those workers employed at time $t$ and not employed at time $t+r$. Non-employed persons are both unemployed, as well as workers employed for less than 15 hours, individuals doing housework, looking after children or other persons and other economically inactive persons. We exclude from the sample individuals in education or training, retired or in community or military service.

Table 6 shows the estimates of the coefficient $\beta$ in such regressions. The results suggest no effect of immigration on the probability of moving out of employment, especially in the short-run. This finding reinforces the idea that the inflow of immigrants creates complementary job opportunities for natives, without hurting their job perspectives. As for the medium- and long-run, using the most demanding specification (column 5) we 
find negative and significant effect of immigration on the probability of becoming nonemployed. Literally this means that in cells with an increase in immigrant share by one percentage point of employment, natives had a smaller probability of finding themselves non-employed after 4 years by 0.22 percentage points. This result is also consistent with the hypothesis that immigrants create new working opportunities in the labor market and, by taking jobs complementary to those of natives, induce stronger job-creation by firms and potentially more employment for natives. Alternatively, as natives move to higher tier occupations, whose unemployment rate is probably lower, they benefit from this upgrade also in terms of employment probability. Our results do not support the idea of crowding out.

As a response to immigration, natives rather than changing occupation, may choose to move within the country. Table 7 explores the effect of immigration on the regional mobility of native workers in the same occupation-country. We compute a dummy equal to 1 when the individual moves out of the region where he/she lived in year $t$, within the following $r$ years and 0 otherwise. The outcome $y$ at the occupation-country-year level is therefore the share of workers who changed the region of residence between time $t$ and time $t+r$. The estimated coefficients from the 2SLS specifications are always nonsignificant and small. At no time horizon (between 2 and 4 years) immigration increases geographical mobility of natives. The results of Tables 6 and 7, together with those of Tables 4 and 5 seem to imply a very clear pattern of response of native workers to immigration. While immigrants do generate a response of natives in the labor market, that response does not seem to be crowding-out, in which natives are moved out of employment, nor a "geographical skating-rink" response, in which natives move out of the region. In fact, we do not find any evidence that either effect takes place. They do, however, tend to push "up" natives in the occupation ladder, hence the appropriate description would be a "bump-up" of native workers. The fact that the local economy absorbs them and tends to accommodate them in higher ranked occupations should also signal that immigrants, while competing for similar jobs, generate a complementary demand for other jobs that attracts natives.

\subsection{Effects on income}

Using information on wage and salary income contained in the dataset, we explore a further potential effect of immigration, in particular the impact on yearly wage, following individuals, as usual, over 2, 3 and 4 years. In particular we compute the individual changes in logarithmic earnings between $t$ and $t+r$ and we then collapse them in country-year-occupation cells. On the one hand, we may expect a positive effect of immigration on wages, due to the occupational upgrade identified before. On the other, occupation upgrading needs not imply significantly higher wages for an individual. In fact, it may take longer than 4 years to accrue measurable income effects. Moreover, immigrant competition may decrease the occupational wages at low level of the ranking (see for instance Bratsberg and Raaum 2012) so that climbing up the occupational ladder simply offsets those potential wage decreases. It would be puzzling, however, to find significant negative wage impact given the observed occupational upgrading.

Table 8 shows that the estimated effect of the foreign born share on average wages and salaries of natives is not significantly different from zero, in all specifications and intervals 
considered. This finding, taken along with the existence of a higher chance of upgrading, should not puzzle as the change of occupation implies, together with an upgrade, also a loss of job-specific human capital in the short-run. Moreover immigrant competition on lower tier occupations may offset part of the positive wage effect of occupational upgrading. By upgrading, people avoid potential negative effects of competition. Moreover positive wage effects from occupational upgrade may need longer time to accrue, once specific human capital is acquired. Therefore, the upward mobility of natives is a very important mechanism to avoid potentially negative competition effects that would occur if natives remained in the same occupation. By pushing natives towards higher ranked occupation, while competing in lower ranked ones, immigrants leave the income of the average native worker roughly unchanged.

\section{The role of institutions}

\subsection{Social expenditures, employment protection and product market competition}

The reallocation of workers towards more skilled occupations can be influenced by individual characteristics, but also by country policies. Here we examine three types of those policies. First, a larger safety net, provided by protective labor market institutions (such as strong unions, high costs of firing, centralized bargaining and similar) may affect the ease and cost of transferring from one occupation to another. Flexible labor markets make the creation of new occupations easier and therefore they may speed up the reallocation of natives. Another important policy is social public expenditure (covering welfare measures for poor families, insurance in case of income losses, disability insurance and others). On the one hand less generous expenditures may induce natives to search for jobs harder, to avoid non-employment. On the other hand, the presence of a protective social net may induce workers to take the risk of changing occupation to find better jobs in the long-run, at the cost of some risk in the short-run.

D'Amuri and Peri (forthcoming) have analyzed the effect of immigrants on aggregate occupational mobility of European workers, dividing countries into those with more and less protected labor markets legislations. In this section we extend that approach and we cover differences in labor market policies, in generosity of social spending and in competition in the product markets. We then classify the countries of our sample according to an index of Employment Protection Legislation (EPL). The index can be computed along different dimensions. In particular OECD (1999) computes three indices of EPL, considering legislation to protect regular workers against dismissal, legislation to regulate temporary work and regulation of collective dismissal. In OECD (1999) these three indicators are consolidated to provide a ranking of countries regarding their overall strictness of employment legislation. To limit the number of specifications and consider a unique measure of EPL, we considered this comprehensive index only. Hence, we define a high EPL dummy variable equal to one if the country has a value of overall EPL greater than the sample average and zero otherwise. We define a low EPL dummy if the country is below the sample mean. We then interact the key control variable, $f_{j, c, t}$, with the high and low dummies. Similarly, we divided our sample in low and high Social Public Expenditure countries, depending on whether the level of spending, as recorded in OECD (2012), is below or above the mean level of the countries considered. ${ }^{8}$ Finally, we also tested whether regulation in the market of products could have any effect on the reallocation of workers into higher skill occupations. We use the OECD Product Market Regulation 
Table 10 Country classification according to employment protection legislation, product market regulation and social expenditure levels

\begin{tabular}{clllll}
\hline \multicolumn{1}{c}{ EPL } & $\begin{array}{c}\text { Product market } \\
\text { regulation }\end{array}$ & Social & EPL & $\begin{array}{c}\text { Low } \\
\text { Product market } \\
\text { regulation }\end{array}$ & $\begin{array}{c}\text { Social } \\
\text { expenditure }\end{array}$ \\
\hline Belgium & Austria & Austria & Austria & Denmark & Greece \\
France & Belgium & Belgium & Denmark & Finland & Ireland \\
Greece & Greece & Denmark & Finland & France & Netherlands \\
Portugal & Portugal & Finland & Ireland & Ireland & Portugal \\
Spain & Spain & France & Netherlands & Netherlands & Spain \\
\end{tabular}

Source: OECD (2012) for Social Expenditure, OECD (2011) for Product Market Regulation and OECD (1999) for EPL.

index (OECD 1999) that measures first, whether countries restrict with licenses and permits the sales of some products and the provision of services, second how strict their anti-trust provisions are and third how regulated some specific markets are. Table 10 provides an overview of the countries classified alternatively as low or high in the three dimensions described.

The results are reported in Table 9. The upper part of the table shows the coefficients on the interaction between the share of foreign born and dummies for high or low values of the policy variables in regressions otherwise identical to equation (1). We include, alternatively social expenditure dummies (Social Exp), product market regulation dummies (PMR) and Employment protection dummies (EPL). We show only the coefficients on those interactions and we limit the analysis to the case in which the dependent variable is occupational upgrading within two years. Each column corresponds to one specification. Focusing on the estimates of the most demanding, column (5) that includes the occupation by year and the country by year effects, the coefficients reveal three interesting facts. First, the estimated effects of immigration on native occupational upgrading is positive for countries with low and high levels of social expenditures, but countries with low social expenditures exhibit larger effects. This is consistent with the idea that less generous social safety net induces workers to upgrade their jobs with higher probability, possibly to avoid the risk of displacement and non-employment in presence of immigrants. Second, when considering upgrading response in countries with high and low EPL, the effect is positive and statistically significant only for countries with low EPL. This suggests that high EPL may constitute "sand in the wheel" of the labor market, especially affecting occupational transition. Finally, immigration is found to have significant and larger effects on occupation upgrade in countries with high product market regulation (PMR). This is an interesting effect that deserves more research. One possibility is that more regulated countries create companies with market power and if workers, especially those in higher ranked occupations, participate to the surplus, then native workers may have more incentives to climb up. Another possibility is that more regulated industries require certified qualifications that immigrants do not easily have, especially at high occupational level. This may further encourage natives to react to migrant inflows, by entering "regulated" positions, facing less competition from immigrants. All the effects are stable across specifications and they are consistent with a story that more competitive labor market, but not necessarily goods market, enhance the occupational response of natives to immigrants. 


\subsection{Policy combinations}

As we have seen that different labor and product market institutions imply a different intensity of native response to immigration, in this section we explore in greater detail whether there is a combination of those two types of policies that is particularly effective in promoting mobility. In the lower part of Table 9 we present the estimates when we interact the share of immigrants with four dummies, covering the four possible combinations of employment protection laws (high and low) and product market regulation policies (high and low). The estimated effect on the interactions are stable across the 2SLS specifications. ${ }^{9}$ They reveal one important regularity. High PMR is a sufficient requisite to have a significant and strong occupational upgrade of natives in response to immigrants. In countries with high EPL there is significant upgrade if the product market regulation is high. This may be due to the fact that in those countries, there are extra profits in the product markets that can be shared by the entrepreneurs and the high-ranked employees. If the higher ranks of the occupational ladder have a profit-sharing arrangement with the employers, and immigration increases the return to the firm, then the incentives to climb the ladder in response to immigration will be particularly strong in those countries. While our simple characterization of policies does not allow us to specify exactly which regulation may have such an effect, still the results clearly suggest that occupational mobility is much more dependent on labor market policies than on product market regulation. Allowing a more open labor market, especially to workers with temporary working contracts, might be good way to promote mobility that could help native in the presence of large inflow of immigrants.

Before concluding, let us notice that the policy analysis is conducted using only 11 points of variation (countries), as the indices used are time invariant. Hence, while interesting and reasonable, the results obtained should be only considered as preliminary and suggestive evidence. Further research in this area is needed before being confident of the relationship between labor market institutions and labor market effects of immigrants.

\section{Conclusions}

In this paper we have analyzed the impact of immigration on several native outcomes. The novelty of the approach is that we use data that allow us to follow native individuals over 2 , 3 and 4 years after they have been exposed to labor market competition from immigrants, measured as their share in the country-year-occupation cell. We first focus on whether the exposure to immigrant competition accelerates or slows the career of native workers, measured as their ability to climb up the occupational ladder. The secondary focus of the study is to see if there are some policies/institutions that help the response of natives to immigration. Using the presence of immigrants from different nationalities in 1991 in European countries and occupations and their inflow during the period 1995-2001 we compare natives exposed to large or small waves of immigrant competition and use this variation to identify the effects on their career.

We find that immigrant competition accelerates the upward potential of natives, increasing their probability of moving to higher occupational tiers. Immigrants fill in several jobs at the "low" end of the occupational spectrum, thus generating opportunities for jobs in higher occupational tiers for natives. This faster mobility does not take place at the cost of higher probability of non-employment. The adjustment process in fact does not imply that some natives are crowded out, but instead that new working 
opportunities are created. Foreigners, by taking jobs complementary to those of natives, induce stronger job-creation by firms and potentially more employment. When considering different institutions, we find that countries with less protective labor markets encourage a significantly stronger upward mobility of natives in response to immigrants. Generosity of the social state does not seem to affect much the response, while product market regulation, possibly creating profits that "upper tier workers" can participate into, also encourages upward mobility. In spite of the worries of European countries, the inflow of immigrants does not seem to product disruptive displacement for native workers, but instead it generates stimulating and positive competition that, in the long run, benefits their careers.

\section{Endnotes}

${ }^{1}$ There are some significant exceptions (Borjas 2003, 2006).

${ }^{2}$ The areas of origin that we construct are; Central and South America, Eastern Europe, Middle East Central Asia, North Africa, North America, Oceania-Pacific, Other Africa, South and Eastern Asia, Western Europe.

${ }^{3}$ We are grateful to an anonymous referee who suggested such a solution.

${ }^{4}$ It should be noticed that ECHP, besides being unable to provide a representative sample of the foreign population in the EU, lacks information on respondents' country of birth as for 4 out of 15 countries, namely Germany, the Netherlands, Greece and Luxembourg.

${ }^{5}$ The ECHP survey records out of employment those workers employed for less than 15 hours, individuals doing housework, looking after children or other person and other economically inactive persons.

${ }^{6}$ All of the OECD Indicators of Product Market Regulation can be found on the OECD's Product Market Regulation Homepage at http://www.oecd.org/eco/pmr. For details on the methodology used for the PMR indices, see, Conway and Nicoletti (2006).

${ }^{7}$ OLS estimates relative to the restricted IV sample indicate that the selection of the countries does not alter the results. The OLS coefficients in the two samples are of comparable magnitude.

${ }^{8}$ Social spending includes unemployment, disability insurance, welfare subsidies and health care.

${ }^{9}$ The F-statistics in these estimations are low. This is due to the fact that we need to instrument four different endogenous variables, one for each combination of policies, with four instruments.

\section{Competing interests}

The IZA Journal of European Labor Studies is committed to the IZA Guiding Principles of Research Integrity. The authors declare that they have observed these principles.

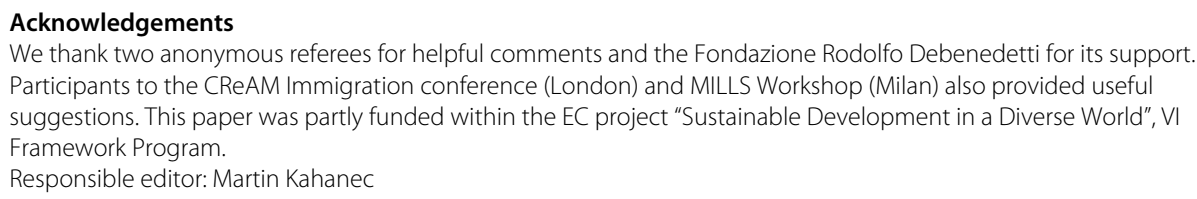

${ }^{1}$ Fondazione Eni Enrico Mattei-FEEM, Corso Magenta, 63, 20123, Milano, Italy. ${ }^{2}$ Department of Economics, Management and Quantitative Methods, Via Conservatorio, 7, 20122, Milano, Italy. ${ }^{3}$ Department of Economics, UC Davis, One Shields Avenue, Davis, CA 95616, USA.

Received: 21 July 2013 Accepted: 4 November 2013

Published: 22 Nov 2013

References

Altonji JG, Card D (1991) The effects of immigration on the labor market outcomes of less-skilled natives. In: NBER

Chapters, Immigration, Trade and the Labor Market. National Bureau of Economic Research, Inc, pp 201-234 
Angrist JD, Kugler AD (2003) Protective or counter-productive? Labour market institutions and the effect of immigration on eu natives. Econ J 113(488): F302-F331, 06

Blanchard O (2006) European Unemployment: The Evolution of Facts and Ideas. Econ Policy 21(45): 5-59

Blanchard O, Wolfers J (2000) The role of shocks and institutions in the rise of european unemployment: the aggregate evidence. Econ J 110(462): C1-33

Boeri T, Terrell K (2002) Institutional determinants of labor reallocation in transition. J Econ Perspect 16(1): 51-76

Borjas GJ (2003) The labor demand curve is downward sloping: reexamining the impact of immigration on the labor market. Q J Econ 118(4): 1335-1374. MIT Press

Borjas G (2006) Native internal migration and the labor market impact of immigration. J Human Resour 41(2): 221-258

Bratsberg B, Raaum O (2012) Immigration and wages: evidence from construction. Econ J 122: 1177-1205

Card D (2001) Immigrant inflows, native outflows, and the local labor market impacts of higher immigration. J Labor Econ 19(1): 22-64. University of Chicago Press

Card, D (2009) Immigration and inequality. Am Econ Rev 99(2): 1-21. American Economic Association

Cohen-Goldner S, Paserman DM (2011) The dynamic impact of immigration on natives' labor market outcomes: evidence from Israel. Eur Econ Rev 55(8): 1027-1045. Elsevier

Conway P, Nicoletti G (2006) Product market regulation in the non-manufacturing sectors of OECD countries: measurement and highlights. OECD Economics Department Working Paper, No 530

D'Amuri F, Giovanni P (forthcoming) Immigration, jobs and employment protection: evidence from europe before and during the great recession. J Eur Econ Assoc

D'Amuri F, Ottaviano GIP, Peri G (2010) The labor market impact of immigration in Western Germany in the 1990s. Eur Econ Rev 54(4): 550-570

Dustmann C, Frattini T (2013) Immigration: the european experience. In: Card D, Raphael S (eds) Immigration, poverty, and socioeconomic inequality. Russel Sage, New York, NY

Dustmann C, Frattini T, Preston I (2013) The effect of immigration along the distribution of wages. Rev Econ Studies 80(1): 145-173

Elias P, McKnight A (2001) Skill measurement in social statistics: recent developments in the uk and the rest of europe Oxf Econ Pap 3: 508-540

European Commission (1996) European Community Household Panel (EHCP): Volume 1 - Survey methodology and implementation. Office for Official Publications of the European Communities, Luxembourg

Eurostat (2009) EU labour force survey database. User guide

Glitz A (2012) The labor market impact of immigration: a quasi-experiment exploiting immigrant location rules in Germany. J Labor Econ 30(1): 175-213

ILO (1990) ISCO-88: International standard Classification of Occupations. Technical Report, ILO Geneve

Lewis E (2011) Immigration, skill mix, and capital-skill complementarity. Q J Econ 126(2): 1029-1069

Nickell S (1997) Unemployment and labor market rigidities: Europe versus North America. J Econ Perspect 11(3): 55-74

OECD (1999) Employment Protection and Labour Market Performance. Employment Outlook- 1999

OECD (2011) Product market regulation database. http://www.oecd.org/eco/pmr

OECD (2012) OECD social expenditure database. www.oecd.org/els/social/expenditure

Ottaviano GIP, Peri G (2012) Rethinking the effect of immigration on wages. J Eur Econ Assoc 10(1): 152-197. European Economic Association

Peracchi F (2002) The European community household panel: a review. Empir Econ 27: 63-90

Peri G, Sparber C (2009) Task specialization, immigration, and wages. Am Econ J Appl Econ 1(3): 135-169. American Economic Association

Peri G, Sparber C (2011) Highly-educated immigrants and native occupational choice. Ind Relat 50(3): 385-411

Scarpetta S (1996) Assessing the role of labour market policies and institutional settings on unemployment: a cross-country study. OECD Econ Stud 26: 43-98

Stock JH, Wright J, Yogo M (2002) A survey of weak instruments and weak identification in generalized method of moments. J Bus Econ Stat 20(4): 518-529

10.1186/2193-9012-2-17

Cite this article as: Cattaneo et al:: Immigration and careers of European workers: effects and the role of policies. IZA Journal of European Labor Studies 2013, 2:17

\section{Submit your manuscript to a SpringerOpen ${ }^{\circ}$ journal and benefit from:}

- Convenient online submission

$\rightarrow$ Rigorous peer review

- Immediate publication on acceptance

- Open access: articles freely available online

- High visibility within the field

- Retaining the copyright to your article

Submit your next manuscript at $\boldsymbol{\triangleright}$ springeropen.com 